\title{
SUBSIDIARITY IN THE UNION LAW: A SUCCESS OR A FAILURE?
}

\author{
C. Lazăr
}

\section{Carmen Lazăr}

Faculty of European Studies, Department of European Studies and Governance

University Babeş-Bolyai of Cluj-Napoca, Cluj-Napoca, Romania

*Corespondence: University Babeş-Bolyai of Cluj-Napoca, 1 Emmanuel de Martonne St., Cluj-Napoca, Romania

E-mail: crmnlazar@yahoo.fr

\begin{abstract}
The principle of subsidiarity has been introduced in the Union law, as a constitutional principle, by the Treaty on the European Union in order to protect the competences and the authonomy of the member States from the interferences of the Union (the European Community at that moment) in the areas of shared competence. It is not sure today that it has succeeded to fulfil this role. Due to their functional nature, the competences of the Union has gradually expanded until now.
\end{abstract}

Key words: subsidiarity, Union, competences, jurisprudence, doctrinal comments

\section{Introduction}

In a previous article we have treated those principles of the European Union law which constitute means of protection of the human rights; more precisely we have approached the most important of them. In the present study we are going to approach the principle of subsidiarity, which is destined - at least at first sight - to protect the competences of the States against the possible interferences of the actions of the European Union, as far as the States and the Union are competent in a field. We shall show the legal definition of this principle and the specifications brought to it by Protocols joined to the treaties, the comments - favourable or not-made on it by the doctrine and the jurisprudence of the Union related to it. We shall not treat procedural aspects related to it, because we did this in a previous article $^{2}$.

\section{Definition and comments}

The principle of subsidiarity has been for the first time introduced in the Treaty establishing the European Economic Community (become later Treaty establishing the European Community - TEC) by the Single European Act of 1986 (SEA) $)^{3}$, but it was applicable at that moment only in the field of the environment. Here is the formula from the art.130R par. 4 of the TEC as introduced by the SEA: "The Community shall take action relating to environment to the extent to which the objectives referred to in paragraph 1 can be attained better at Community level than at the level of the individual Member States..." Later, the Treaty on the European Union (TEU, called then the Treaty of Maastricht) of $1992^{4}$

\footnotetext{
${ }^{1}$ See Carmen-Nora Lazăr, Principiile generale ale dreptului Uniunii Europene - mijloace de protecție a drepturilor omului, in Contemporary legal institutions in the context of the integration in the EU, Universul Juridic Publishing, Bucharest, 2012, pp. 101-112.

${ }^{2}$ See Carmen-Nora Lazăr, Rolul parlamentelor națiionale în tratatele anterioare ale Uniunii Europene şi ale Comunităţilor Europene şi în Tratatul de la Lisabona, in Dreptul no. 6/2010, pp. 203-209.

${ }^{3}$ Entered into force in 1987.

${ }^{4}$ Entered into force in 1993.
} 
has generalized it, making it a principle which governs the exercise of the Community competences; so, the art. 3B al. 2 from the TEC as modified by the TEU provided: "in areas which do not fall under its exclusive competence, the Community shall take action, in accordance with the principle of subsidiarity, only if and in so far as the objectives of the proposed action cannot be sufficiently achieved by the Member States and can therefore (emphasis added by us), by reason of the scale or effects of the proposed action, be better achieved by the Community"s; this is correlated with the idea affirmed in the art. A (common provisions) from TEU that the decisions in the Union are taken as closely as possible to the citizen $^{6}$. We can remark a difference in comparison with the definition from the SEA: while this last required only that the Community action be able to achieve the objectives pursued, thus it being not necessary that the action of the Community be more satisfactory than that of the States, the TEU requires two cumulative conditions; also, while in the SEA only the action of each Member State is taken into acount in order to see if it is satisfactory, the definition of the TEU does not anymore specify anything in this respect, which will raise a problem (see below). The definition given by the actual art. 5 par. 3 from TEU (common provisions) as modified by the Treaty of Lisbon of $2007^{7}$ is maintained in essence: "Under the principle of subsidiarity, the Union shall act only if and in so far as the objectives of the proposed action cannot be sufficiently achieved by the Member States, either at central level or at regional and local level, but can rather (emphasis added by us), by reason of the scale or effects of the proposed action, be better achieved at Union level". The word "therefore" is suppressed ${ }^{8}$; concerning the level of the States, the treaty specifies that it may be the central, the regional or the local level, taking into account the territorial structure of the States and the distribution of the competences within them; curiously, the word "rather" is not present in other linguistical variants of the treaties (those whose language is accessible to us, i.e. those in Spanish, in Portuguese, in Romanian, in Italian, in French and in German) and moreover it does not make sense. Obviously, the idea mentioned above - that the decisions are taken as closely as possible to the citizen - is maintained (in art. 1 of the TEU - common provisions).

We observe that the subsidiarity is a principle which governs the use of the Union conpetences and not their delimitation from those of the States, as the principle of conferral does (whose logical consequence it is considered by some authors ${ }^{9}$ ). It is applicable all the times that it is about non-exclusive competences, which means that, theorically, these competences may be shared, of coordination of the economic and employment policies of the States, of defining and implementing a common foreign and security policy (which is, in essence, also a shared competence) or of coordination/supporting/supplementing of the actions of the States in purely national areas ${ }^{10}$. Previously to the Treaty of Lisbon, though,

\footnotetext{
${ }^{5}$ We observe that by using the word "therefore" the treaty wanted to underline a consequence which results automatically, necessarily, from the previous idea; or, this is not exact, because if the actions of the States are not satisfactory this does not mean that the action of the Community (now the Union) will be automatically satisfactory.

${ }^{6}$ See also S. Sieberson, Dividing lines between the European Union and its Member States, "T.M.C. Asser Press" Publishing House, Hague, 2008, p. 139.

${ }^{7}$ Entered into force in 2009.

${ }^{8}$ Other authors too consider that this suppression is a progress (see A. von Bogdandy, J. Bast, The federal order of competences, in A. Von Bogdandy, J. Bast, Principles of European constitutional law, "Hart" Publishing, Oxford-USA-Canada, “C.H.Beck” Publishing House, München, 2009, p. 302).

${ }^{9}$ S. Sieberson, op. cit., pp. 142-143; T. van den Brink, The substance of subsidiarity: the interpretation and meaning of the principle after Lisbon, in M. Trybus, L. Rubini, The Treaty of Lisbon and the future of European law and policy, "Edward Elgar" Publishing House, Great Britain-USA, 2012, pp. 160-161).

${ }^{10}$ We consider, though, that practically the subsidiarity is not applicable to the other types of competences than those shared and that of defining and implementing a common foreign and security policy because it, by definition, permits only the intervention at a single level, either of the Union or of the States. Or, in the cases of coordination/supporting/supplementing, the intervention takes place at both levels, although it is of a different type: the States take a measure (either a policy or an action) and the Union coordinates it for all or supports it or
} 
when a classification of the Community competences did not exist in the treaties and was the "creation" of the jurisprudence through the interpretation of the treaties, the principle of subsidiarity was difficult to apply ${ }^{11}$. With regard to the nature of the acts, the question is if the subsidiarity mentioned in the art.5 TEU refers only to the legislative acts, thus to the legislative competence, or also to the implementing acts, to the implementing competence. In our opinion the subsidiarity provided there is applicable only to the legislative competences ${ }^{12}$, because the implementing competences are referred to separately, respectively the delegated implementing competences in art. 291 par. 1 and 2 of Treaty on the functionning of the European Union (TFEU) and the own implementing competences in various provisions of the same treaty (see below). Art. 291 TFEU contains the subsidiarity without affirming it expressely: "1. Member States shall adopt all measures of national law necessary to implement legally binding Union acts. 2 . Where uniform conditions for implementing legally binding Union acts are needed (emphasis added by us), those acts shall confer implementing power on the Commission or, in duly justified specific cases and in the cases provided for in art. 24 and 26 TEU, on the Council". Concerning the own implementing competences of the Union (more precisely of the Commission), i.e. those provided directly by the treaties, they are: the adoption of directives or decisions addressed to the States concerning the public enterprises or the enterprises with special regime which provide services of general interest (art. 106 par. 3 TFEU); the adoption of regulations concerning the right of permanent residence of the employees nationals of another State (as a component of the freedom of movement; art. 45 par. 3 d TFEU); the adoption of regulations concerning the competition (art. 105 par. 3 TFEU); the execution of the Union budget (art.317-319 TFEU). With regard to the first the subsidiarity cannot apply because it would not make sense that the States address to themselves directives or decisions! With regard to the last the subsidiarity cannot apply because it is an exclusive competence of the Union. With regard to the right of residence and to the competition ${ }^{13}$, they contain cross-border elements, the first by its nature, the second by hypothesis; it results, thus, that the subsidiarity is not applicable also here, the two provisions containing an absolute presumption in favour of the Union level. Moreover, the two Protocols on the application of the principles of subsidiarity and proportionality, annexed to the Treaty of Amsterdam and, respectively, to the Treaty of Lisbon, mentioned below, make reference to the legislative acts. The difference between the art. 5 and the art. 291 TFEU is that in the case of the implementing competences the non-respect of the subsidiarity may not be imputable to the implementing act itself, because it is adopted on empowerment by the legislative act, but to this last also, as in the hypothesis provided by the art. 5 .

\footnotetext{
supplements it. On the other hand, in the case of the last type of competences the intervention of the Union may not be imposed to the States, even if it is necessary; moreover, the treaty itself provides in this case that the Union may not supersede the competences of the States. Also, it does not apply to the competences of control or of delivering opinions (see the decision of the European Court of Justice - ECJ - "Commission/Germany" 539/09 of 15.11.2011, http://curia.europa.eu/). The subsidiarity remains thus to apply only to the shared competences (including, as we said, the common foreign and security policy).

${ }^{11}$ Josephine Steiner, Lorna Woods, EU Law, "Oxford University Press" Publishing House, New-York, 2009, p.61; N. Foster, Foster on EU Law, "Oxford University Press" Publishing House, Oxford, 2009, p. 94.

${ }_{12}$ Despite the defectuous, redundant wording of the art. 2 TFEU: "Only the Union and the states may legislate and adopt legally binding acts..." (emphasis added by us), respectively "The Union and the States may legislate and adopt legally binding acts..." (emphasis added by us), the notion of legally binding acts covering also the implementing acts (be they normative or individual).

${ }^{13}$ We specify that it is about the competition which overcomes the borders of a single State, otherwise the competence belongs to the State concerned (according to the art. 3, par. $1 \mathrm{~b}$ of the TFEU).
} 
In case of doubt with regard to the satisfactory character of the action of the States, the provision of the TEU contains a presumption in favour of the inferior level; this result from the cumulative character of the conditions required (see below) ${ }^{14}$.

Because, according to the opinion of some authors, the mentioned provisions do not contain a definition of the principle but of its way of use ${ }^{15}$ and according to the opinion of others the definition is vague, unclear, unprecise ${ }^{16}$, the Protocol on the application of the principles of subsidiarity and proportionality joined to the Treaty of Amsterdam of $1997^{17}$ has brought some specifications in the matter and has formulated for the institutions requirements with regard to this principle. Thus, in order to verify the fulfilment of the two conditions mentioned in the treaty, three criteria must be taken into account: the existence of crossborder aspects, which cannot be satisfactorily regulated by the States; the action of the States or the absence of the action or the Community would conflict with the requirements of the treaty (for example the necessity to correct the distorsions of competition, to avoid the disguised restrictions brought to the changes or to strenghten the economic-social cohesion) or would damage seriously in another way the interests of the States; an action at Community level would have obvious benefits in comparison with an action of the States, by reason of its scale or effects. In fact a test of comparative efficiency is made ${ }^{18}$. Although it is sustained that it is not clear if the three criteria are cumulative or alternative, in our opinion they may not be but alternative, this resulting logically from the manner in which they are fomulated ${ }^{19}$. Some authors consider though that it is not possible to establish a priori clear and abstract criteria for the evaluation of the subsidiarity, because all the areas are closely connected between them and all have a connection with the common market (the main objective of the treaties, n.n.), so that an intervention of the Union shall always be necessary, even if in a reduced degree $^{20}$. Then, in accordance with the Protocol, the form of the Community action must be the simplest possible permitted by the adequate attainment of the objectives of the measure and by the necessity of an effective execution. It is recommended to give priority to the directives over the regulations, respectively to the frame-directives over the detailed directives; one can add the recommendations, the guides, the codes of conduct ${ }^{21}$, all nonbinding instruments for those to whom they are addressed, forming what some call the "soft law"; also, the idea contained in the Protocol would impose to have recourse to minimal harmonizations, respectively to the mutual recognition instead of harmonization ${ }^{22}$. Regarding the nature and the scale of the Community action, it is specified that the measure must leave to the States a margin of action as great as possible but compatible with the requirements of the treaties and with the necessity of the attainment of the objectives of the measure; the well established national practices and the national legal systems must be respected; the States

\footnotetext{
${ }^{14}$ Alina Kaczorowska, EU Law, "Routledge-Cavendish" Publishing House, Great Britain-USA-Canada, 2009, p. 102; T. Konstandinides, Division of powers in EU Law, "Wolters Kluwer" Publishing House, Hague, 2009, p. 123

${ }_{15}^{15}$ T. Konstandinides, op. cit., p. 124

16 T. van den Brink, op. cit., p. 160-161; N. Foster, op. cit., p. 94; S. Sieberson, op. cit., p. 123; in T. Konstandinides, op. cit., p. 121.

${ }^{17}$ Entered into force in 1999.

${ }^{18}$ Josephine Steiner, Lorna Woods, op. cit., p.62; D. Chalmers, G. Davies, G. Monti, European Union law: cases and materials, "Cambridge University Press" Publishing House, Cambridge, 2010, p. 364.

${ }^{19}$ In the same sense see J.-P. Jacqué, Droit institutionnel de l'Union Européenne, "Dalloz" Publishing House, Paris, 2009, p. 166.

${ }^{20}$ P. Craig, Grainne de Burca, EC Law. Texts, Cases \& Materials, "Oxford University Press" Publishing House, Great Britain, 2008, p.95; according to the functionalist theory, on which the Communities are founded, the necessity to attain an objective in an area imposes the institution of competences in another areas too, because of the close connection between them, as the "rule of snowball" works; thus, the competences are based on objectives, not on areas.

${ }_{21}^{21}$ P. Craig, Grainne de Burca, op. cit., pp. 95-97; Alina Kaczorowska, op. cit., pp. 99-100.

${ }^{22}$ P. Craig, Grainne de Burca, ibidem; Alina Kaczorowska, ibidem.
} 
must be offered different solutions for the attainment of the objectives of the measure, subject to the ensurance of an adequate execution. The institutions must reason each legislative act with regard to the respect of the subsidiarity principle, in the exposé of reasons which accompanies it; they must take into account the necessity that each kind of burden (administrative, financial, etc.) imposed on the Community, on the States, on the local authorities or on the individuals (economic operators or private persons) be as low as possible. The Commission, moreover, must proceed to social consultations as large as possible before proposing a legislative act. According to the Protocol, the subsidiarity is a dynamic concept, which permits both an extension of the Community actions, when the circumstances require it and within the limits of its competences, and a limitation or a cessation of these actions, if they are not anymore justified ${ }^{23}$.

The Protocol having the same object joined to the Treaty of Lisbon maintains the requirements previously instituted with regard to the obligation of social consultation, specifying moreover that the regional or local scale of the proposed action must be taken into account, to the obligation of reasoning of the legislative acts with regard to the subsidiarity (but, instead the exposé of reasons, the act must be accompanied by a slip which contains elements based on qualitative and, if possible, quantitative indicators which permit the evaluation of the proposed measure), to the obligation to take into account that any imposed burden be the lowest. We do not mention anymore here the procedure of parliamentarian control instituted by the Protocol because, as we have specified in the Introduction, we have done it in a previous article.

Having in view that the principle of subsidiarity is correlated with the idea that the decisions must be taken as closely as possible to the citizens - the principle proceeding just from this necessity -, it can be sustained that only at a first impression, more precisely that its role is only apparently to protect the competences of the States, ultimately the citizens being those it concerns. This because the State is not a goal in itself and its competences are tasks given in order to satisfy social needs; on the other hand, the democracy supposes that the citizens participate to or influence the decision-making; or, the more distant is the level of the decision-making, the weaker is the participation or the influence of the citizens (if it exists; let us remember that until a given moment the European Parliament, which represents the citizens of the Member States, had not a proper power of decision but only an influence, at the beginning weak and later stronger, on the decision factors). So that, in our opinion, it cannot be sustained, as some authors do, that the principle of subsidiarity is not of a nature to interest the citizens because it is indifferent for them at what level the decisions are taken ${ }^{24}$.

The principle of subsidiarity has appeared, as it is shown, in a context in which the Community competences had very much expanded (either by revisions of the founding treaties, or by the use of the flexibility clause - the actual art. 352 TFEU $^{25}$ ) and some States and the individuals had the impression that they (the competences) can expand undefinitely, due to their functional nature; other States, with a federal structure or only regionalized, feared that the expansion of the Community competences would affect the balance and the distribution of their internal competences; the individuals saw that their life was more and more regulated at a more distant level from them; more generally, the States feared that in the areas of shared competence their freedom of action would diminish, especially that more and more decisions were going to be taken with qualified majority ${ }^{26}$. Thus, the principle was going

\footnotetext{
${ }^{23}$ In this sense an author showed that the subsidiarity is not equivalent to the decetralization, just because it allows power either at the superior level or at the inferior one, depending on the necessities (T. Konstandinides, op. cit., p. 124; Alina Kaczorowska, op. cit., p. 197).

${ }^{24}$ N. Foster, op. cit., p. 96.

${ }^{25}$ This provision is applicable in the case in which the treaties assign to the Union an objective but they do not give it also the corresponding means (the legal acts), the Council being allowed to establish them by unanimity

${ }^{26}$ J.-P. Jacqué, op. cit., pp. 162-164.
} 
to refocus the process of exercise of governmental functions from the centre to the periphery ${ }^{27}$, to put an end to the tendencies considered to be federalist of the Community ${ }^{28}$, although it was accepted also by the supporters of the federalism and by those who were hostile to such an evolution ${ }^{29}$. The explanation of its general acceptance is, probably, that it is of a nature to lead both to the expansion and to the limitation of the intervention of the Union, depending on the necessities, (as the Protocol mentioned above remarks), being both an integrationist and an anti-integrationist principle, having thus both a positive and a negative $\operatorname{aspect}^{30}$.

As it was remarked, before being consecrated as such the subsidiarity was (and continue to be) implicitely contained in more provisions of the treaties: in the flexibility clause provision (see previously), in that related to the implementing competences (see previously), in that related to the margin of appreciation of the States when they implement a directive (art. 288 par. 3 TFEU), in those related to the mutual recognition between the States of the standards, diplomas, certificates etc., in the rule of reason ${ }^{31}$ with regard to the freedom of movement ${ }^{32}$; in a larger sense, it is considered that also the conferral of competences on the Community/Union, both initially and later - by revisions of the treaties -, contains implicitely the principle of subsidiarity, this being inherent to any system with more levels of governance $^{33}$.

Despite of the fact that the principle of subsidiarity is necessary, in our opinion, if the preservation of the national authonomy is wanted, it is far to make unanimity in the literature. Some authors have considered that it is mistaken, appeared in an improper moment and irrelevant for the Union law because it is born in another sphere, that of the relationships individual-society-State (for this reason it is also irrelevant for the federal States) ) $^{34}$; being unclear and unprecisely defined and, for this reason, being difficult to be controlled by judicial way, having moreover a defensive nature, it is not able to establish a balance between the Union and the States ${ }^{35}$, it cannot represent an adequate guarantee against the unjustified expansion of the Union competences ${ }^{36}$, it does not meet the concerns for the preservation of the competences of the States and it did not succeed to contain the centralizing trend of the power $^{37}$. For these reasons some consider that the proportionality ${ }^{38}$, respectively the sovereignty ${ }^{39}$ are more important than the subsidiarity; anyway, the subsidiarity is not

\footnotetext{
${ }^{27}$ T. Konstandinides, op. cit., p. 118.

${ }^{28}$ P. Craig, Grainne de Burca, op. cit., p. 94.

${ }^{29}$ J.-P. Jacqué, op. cit., p. 161.

${ }^{30}$ Idem, p. 165; P. J. G. Kapteyn e.a., The law of the European Union and the European Communities, Ed. Wolters Kluwer, USA-The Netherlands, 2008, p. 171; T. Konstandinides, op. cit., p. 120; other authors define inversely the positive and the negative aspect, the first meaning the limitation of the Union competences and the second the prevention of the action of the States (and, thus, the permission of the Union action) (see T. Konstandinides, op. cit., pp. 124-125).

31 This concept, (deliberately) incompletely provided in the treaties, was completed by he ECJ through interpretation; it refers to the derogations - non-provided by the treaties - which the Member States may bring to the freedom of movement under the control of the ECJ, this last having the role to appreciate the reasonable character, the rightness of these derogations.

${ }^{32}$ N. Foster, op. cit., p. 93; Alina Kaczorowska, op. cit., p. 97; J.-P. Jacqué, op. cit., p. 160.

33 J.-P. Jacqué, ibidem.

${ }^{34}$ P.J.G. Kapteyn e.a., op. cit., pp. 139-140.

${ }^{35}$ T. van den Brink, op. cit., pp. 160-161; P. Craig, Grainne de Burca, op. cit., p. 100.

${ }^{36}$ P.J.G. Kapteyn e.a., op. cit., pp. 139-140.

${ }^{37}$ Ibidem; T. Konstandinides, op. cit., p. 120.

${ }^{38}$ T. van den Brink, op. cit., p. 160; P. Craig, Grainne de Burca, ibidem.

${ }^{39}$ P.J.G. Kapteyn e.a., op. cit., pp. 139-140; this because the Union is however an international organization, so that in its relationship with the Member States the problem would be that of the respect of the sovereignty and not that of the subsidiarity.
} 
sufficient to involve the citizens in the decision-making ${ }^{40}$, idea to which we cannot but to subscribe.

It is to be mentioned also the fact that neither the procedure instituted by the Treaty of Lisbon with the view to monitor previously the respect of the principle of subsidiarity has been exempted from criticism. Indeed, this procedure encumbers and slows the decisionmaking process - despite of the fact that its simplification has been wanted all the time -, without the national parliaments being able to block the adoption of an act which is deemed to violate the subsidiarity ${ }^{41}$. If we agree with the criticism concerning this last aspect, we do not share it also for the rest. Any democratic process, by the fact that it involves more actors ${ }^{42}$, is par excellence complex and complicated; only the dictatorship is simple! Without the ordinary legislative procedure - the former co-decision -, the European Parliament would have neither today a decisive word to say in the decision-making process (which has given birth to the criticism concerning the "democratic deficit" of the Union). Certainly, even here some questions may be raised, for example referring to the obligation of the governments of the Member States to represent before the jurisdiction the parliaments of their own States in an action based on the non-respect of the principle of subsidiarity, if they do not agree with the action $^{43}$. The Protocol joined to the Treaty of Lisbon provides that the obligation mentioned is exercised "in accordance with the legal order of the States". Does this mean that the existence itself of the obligation or only the conditions of its exercise depend on the provisions of the legal order of the States? In our opinion the answer is the second variant, otherwise the provisions of the Protocol would be void of content and the national parliaments which want to bring judicial proceedings, if they did not succeed to prevent the adoption of an act "accused" to violate the subsidiarity, would be at the mercy of their own governments, which would not be normal ${ }^{44}$. Anyway, it is important that the monitoring of the respect of the subsidiarity be made also prior to the adoption of a legislative act, even in the absence of a veto from the national parliaments or from another factors, this influencing too the effectiveness of the principle ${ }^{45}$.

Relatively to the subsidiarity more questions have been raised ${ }^{46}$. First, the action of the States should be appreciated with reference to the actual, present situation, or to the future, potential one? We agree with the opinion that, having in view the terms of the treaty, one must take into acount what the States could do in the future ${ }^{47}$. Second, one must take into account the action at the level of each State (thus isolately, individually) or, to the extent that an agreement is concluded between all the States, the collective action resulted? In other words, is the intervention of the Union justified if the objective can be attained by a collective action of all the States, given that the action of each State would not be able to attain it? We saw that the SEA has referred only to the individual States, so the answer would be clear here. The opinions are shared, some sustaining that, although in accordance with the letter of the treaties, an agreement between all the Member States violates their spirit, pursuing to attain an objective out of the frame of the Union and through an instrument which is not an act of Union law but one of international law, thus taken away from the judicial control of the $\mathrm{ECJ}^{48}$;

\footnotetext{
${ }^{40}$ J.-P. Jacqué, op. cit., p. 161; this author considers that the problem does not reside in the fact that the Union has too many competences, but in their way of use (idem, p. 164).

${ }^{41}$ T. Konstandinides, op. cit., p. 151; S. Sieberson, ibidem; the first author considers even that the procedure instituted is destined more to solve the problem of the Union legitimacy than the problem of its competences.

${ }^{42}$ Thing that, moreover, even some critics appreciate as being, though, an advantage (T. Konstandinides, ibidem; A. von Bogdandy, J. Bast, op. cit., p. 304).

${ }^{43}$ T. Konstandinides, op. cit., p. 150.

${ }^{44}$ In an opposite sense see A. von Bogdandy, J. Bast, op. cit., p. 303.

${ }^{45}$ T. Konstandinides, op. cit., p. 121.

${ }^{46}$ For all these questions see J.-P. Jacqué, op. cit., pp. 166-168.

${ }^{47}$ Ibidem, pp. 166-167.

${ }^{48}$ In J.-P. Jacqué, op. cit., p. 167 (the author agrees with this opinion).
} 
others, as well the ECJ itself, consider though that, in so far as the States are (also) competent in an area, they may exercise their competence as they want, inclusively by an agreement to which all of them are parties, the treaties not instituting restrictions in this respect ${ }^{49}$. Third, the action of the private partners (natural and legal persons) can be taken into account where we speak about the action of the States? Theorically, having in view the terms of the treaties, which refer to the States, this is not possible ${ }^{50}$; the individuals may not be assimilated to the States, however we force the interpretations. Practically, though, the Commission takes into account the measures that the individuals take with the view to attain objectives of the Union (for example through agreements between trade associations and employers organizations) and gives up to propose legislative acts in that matter ${ }^{51}$.

On the other hand, if it is considered that legally speaking the principle has and will have only an insignificant impact - i.e. it has not led and will not lead to the reduction of the intervention of the Union -, from a political point of view it represents an engagement toward democracy and toward decentralization, conferring legitimacy to the Union, in opposition with the nationalist trend, which focuses on the legitimacy of the States ${ }^{52}$.

\section{Jurisprudence and comments}

Even from the beginning the problem has been raised if the principle of subsidiarity is of a nature to be invoked before the jurisdictions, more precisely before the Union jurisdictions. Some authors, arguing its partially political nature ${ }^{53}$ and the vague character of its definition, have sustained that it may not be invoked judicially ${ }^{54}$, but others have shown that the vagueness and the lack of clarity have not made other concepts unable of judicial review $^{55}$; also, the fact that the jurisdiction must appreciate the opportunity and the necessity is not an obstacle against the judicial review, which has been and is exercised in other similar situations $t^{50}{ }^{56}$, even if it is limited to establish if the institution has not committed a manifest error of appreciation. Neither the jurisprudence of the ECJ has followed the first point of view, accepting even early ${ }^{57}$ to review the legislative Community acts (also) with regard to the respect of the subsidiarity, although, really, its control has been limited to verify if the acts were dully reasoned in this respect ${ }^{58}$, with the specification that in the point of view of the ECJ at that moment the reasoning did not need to be detailed and neither to make an express reference to the principle of subsidiarity; the Union jurisdiction has not applied itself, thus, the test of comparative efficiency based on the criteria from the Protocol previously mentioned ${ }^{59}$.

\footnotetext{
49 In J.-P. Jacqué, ibidem; opinion of he ECJ 1/94 of 15.11.1994, http://curia.europa.eu/; decision ECJ "Parliament/Council" 316/91 of 2.03.1994, http://curia.europa.eu/; decision ECJ "Commission/Council" 22/70 of 31.03.1971, http://curia.europa.eu/; decision ECJ "Parliament/Council and Commission" 181/91 of 30.06.1993, http://curia.europa.eu/; the author cited shows, though, that, because in two of these cases it was about competences of coordination and not of shared competences, the reasoning of the Court could not be extended to these last; we are not of this opinion, the Court having used general terms ("non-exclusive competences", which means all the other types).

${ }^{50}$ J.-P. Jacqué, op. cit., pp. 167-168; in an opposite sense see Alina Kaczorowska, op. cit., p. 151.

${ }^{51}$ J.-P. Jacqué, ibidem.

${ }^{52}$ S. Sieberson, op. cit., p. 143

${ }^{53}$ Because it implies the appreciation of the opportunity and the necessity of a measure

${ }^{54}$ Josephine Steiner, Lorna Woods, op. cit., p.62

${ }^{55}$ In T. van de Brink, op. cit., p. 160

${ }^{56}$ For example in the case of the principle of proportionality

${ }^{57}$ Decision of the ECJ "Great Britain/Council" 84/94 of 12.11.1996, http://curia.europa.eu/; decision of he ECJ "Germany/Parliament and Council" 233/94 of 13.05.1997, http://curia.europa.eu/; we mention that in the first case the subsidiarity has not been invoked separately but in connection with the legal basis of the act

${ }^{58}$ The obligation of reasoning is a general one, having to be respected for each act, irrespective of its nature and rank; also, we mention that the non-respect of the subsidiarity may be invoked in the frame of the existing procedures, i.e. in an action in annulment, in a preliminary ruling in validity and through the plea of illegality in any type of direct action (see in the same sense Josephine Steiner, Lorna Woods, op. cit., p.62; T. van den Brink, op. cit., p. 163)

${ }^{59}$ T. van den Brink, op. cit., p. 163.
} 
Subsequently to that Protocol, the jurisprudence has evolved in the sense of the deepening of the review, the jurisdiction verifying itself if the requirements of the Community action are satisfied with reference to the criteria from the Protocol ${ }^{60}$. Having in view the provisions of the Protocol, it would have been impossible for the ECJ to not take it into account and to not evolve from a purely formal review to a substantial one ${ }^{61}$; all the more after the entry into force of the Treaty of Lisbon with the afferent Protocol - thus with the new procedure of $a$ priori control and with the possibility of the introduction of an action in annulment by the national parliaments and by the Comitee of Regions - the ECJ could not maintain its former position $^{62}$. However, as the doctrine remarks, having in view the great power of appreciation from which benefit in principle the institutions, even a substantial review is not and cannot be, inevitably, but a marginal one, limited to the ascertainment of the existence of a manifest error of appreciation; otherwise the jurisdiction should make complex social-economic assessments and calculations, which would mean that it substitutes itself for the competent institutions ${ }^{63}$. Moreover, since a measure has been proposed by the Commission and adopted by the Council and, in principle, by the Parliament too, its invalidation by the Union jurisdiction by reason of the non-respect of the subsidiarity would be equivalent to say to the respective institutions that all have been wrong, that all have mistaken about ${ }^{64}$. We would add that, if a measure is taken with unanimity, the jurisdiction must show even more restraint, because it is supposed that the subsidiarity protects just the authonomy of the States; or, these have give up to its benefit by voting in favour of the measure. Also, the jurisdictions of the Union do not benefit from electoral legitimacy and a larger review would curb the development of the competences of the Union, i.e. the European integration; if in other respects the ECJ has shown militancy, being accused for the "government of judges", this has happened just in cases in which an impulse to the integration, endangered by the inaction of the political decisional factors and by the non-respect by the States of the requirements of the treaties, had to be given ${ }^{65}$.

What could be inferred from the jurisprudence so far of the ECJ? From a statistical point of view the subsidiarity has been invoked as a ground of nullity ${ }^{66}$ in few cases from the total number of acts adopted by the Union ${ }^{67}$ and it is to be specified that it was invoked rarely alone (probably because the claimants appreciated that otherwise they had few chances of

\footnotetext{
${ }^{60}$ Decision of the ECJ "The Netherlands/Parliament and Council" 377/98 of 9.10.2001, http://curia.europa.eu/; decision of ECJ "Alliance for Natural Health and Nutri-Link Ltd e.a." 154-155/04 of 12.07.2005, http://curia.europa.eu/; decision ECJ "B.A.T. e.a." 491/01 of 10.12.2002, http://curia.europa.eu/; decision ECJ "Commission/Germany" 103/01 of 22.05.2003, http://curia.europa.eu/; decision ECJ "Vodafone" 58/08 of 8.06.2010, http://curia.europa.eu/ (even in this period, though, there are decisions in which the reasoning on subsidiarity is lacunar or which are limited to the analysis of the reasoning of the act; see decision of the former Court of First Instance, actual General Court, "GSK Services Unlimited/Commission” 168/01 of 27.09.2006, http://curia.europa.eu/; decision of the ECJ "Commission/Germany" 518/07 of 9.03.2010, http://curia.europa.eu/).

${ }^{61}$ T. Konstandinides, op. cit., pp. 136-137.

${ }^{62}$ T. van den Brink, op. cit., p. 164; Alina Kaczorowska, op. cit., p. 65; J.-P. Jacqué, op. cit., p. 168; however, it is sustained that in the action in annulment brought by the national parliaments - through their governments the jurisdiction may not review but the respect of the a priori procedure, not other aspects too (see $\mathrm{T}$. Konstandinides, op. cit., p. 150); we confess that we do not see on what such an affirmation is based!

${ }^{63}$ P. Craig, Grainne de Burca, op. cit., p.99; J.-P. Jacqué, op. cit., p. 168; P.J.G. Kapteyn e.a., op. cit., p. 143 ; T. Konstandinides, op. cit., pp. 131-136; this last author considers that the treaty itself is ambiguous with regard to the scale of the judicial review, it does not result from it if the review must be a purely formal, procedural one (i.e. limited to the reasoning of the act and to the respect of the a priori procedure) or also a substantial one (idem, p. 152); in our opinion, since it is not specified in the treaty, the review must be complete, i.e. focus on all the aspects, even if it is limited with regard to its intensity.

${ }^{64}$ D. Chalmers, G. Davies, G. Monti, op. cit., p.364 and pp. 365-366.

${ }^{65} \mathrm{~T}$. Konstandinides, ibidem.

${ }^{66}$ In this respect it is included in the larger ground, i.e. the infringement of the treaties and of the acts adopted for their application.

${ }^{67}$ P. Craig, Grainne de Burca, op. cit., p. 100.
} 
success); often it was invoked as an accessory ground of the legal basis. Also, an uniformity of attitudes between the Member States does not exist. For example, the most times the claimants were natural/legal persons, not States, although it is supposed that the subsidiarity protects the competences of those! One reason for which the individuals have invoked the subsidiarity is that mentioned previously, i.e. the fact that it is not indifferent for them at what level the power is exercised. Then, many times some States have intervened in the defense of the act (which is not surprisingly if they have voted in its favour), while rarely one State has intervened in the defense of the individual claimant ${ }^{68}$. Finally, the most important observation would be that never the jurisdiction has annulled an act exclusively on the ground of the nonrespect of the subsidiarity ${ }^{69}$. Some authors are of opinion that, even if the review was more intense, it would not be sure that the result would be other, i.e. the act would be annulled on this ground $^{70}$. The explanation for the restraint of the Union jurisdiction consists in those shown previously; before the Treaty of Lisbon, the fact that the classification of the Union competences was just the creation of the jurisprudence was another argument ${ }^{71}$.

These results, not just glad, gives the right to some to sustain that a substantial review of the respect of the subsidiarity does not make sense, having to limit itself to formal, procedural aspects ${ }^{72}$. We do not agree with such an affirmation, even we observe that, really, so far the jurisprudence is disappointing. Anyway, it is probably that the subsidiarity will influence the interpretation of the Union law - with regard to its content and scope -, if it is not a ground of invalidity/nullity ${ }^{73}$.

\section{Conclusions}

How the result of a few years of application of the principle of subsidiarity can be appreciated? In fact it is difficult to say clearly, without no doubt, that the result is positive or negative. It is likely, though, that the result is under the expectations. If the jurisprudence is really disappointing, we must wait to see how the a priori procedure of the monitoring the respect of the subsidiarity by the national parliaments works; it is too early to say something in this respect. If the national parliaments, which so far had not any role in the Union decision-making process, take seriously their role attributed by the Protocole joined to the Treaty of Lisbon, it is sure that the initiators of a legislative act - firstly the Commission - be more cautious, more prudent to propose something which does not respect the subsidiarity; also, the legislator - the Council or/and the Parliament - will pay more attention to this aspect. As a result, it is likely that the jurisprudence will change too and not only with regard to the procedural aspects, but also with regard to the substantial aspects.

\section{Bibliography}

M. Trybus, L. Rubini, The Treaty of Lisbon and the future of European law and policy, "Edward Elgar" Publishing House, Great Britain-USA, 2012;

D. Chalmers, G. Davies, G. Monti, European Union law: cases and materials, "Cambridge University Press" Publishing House, Cambridge, 2010;

A. von Bogdandy, J. Bast, Principles of European constitutional law, "Hart" Publishing House, Oxford-USA-Canada, “C.H.Beck” Publishing House, München, 2009;

N. Foster, Foster on EU Law, "Oxford University Press" Publishing House, Oxford, 2009;

J.-P. Jacqué, Droit institutionnel de l'Union Européenne, "Dalloz" Publishing House, Paris, 2009;

\footnotetext{
${ }^{68}$ Ibidem.

${ }^{69}$ Ibidem; T. Konstandinides, op. cit., p. 131.

${ }^{70}$ P. Craig, Grainne de Burca, ibidem.

${ }^{71}$ Alina Kaczorowska, op. cit., p. 152.

${ }^{72}$ T. Konstandinides, op. cit., p. 122.

${ }^{73}$ Idem, p. 137.
} 
Alina Kaczorowska, EU Law, "Routledge-Cavendish" Publishing House, Great Britain-USACanada, 2009;

T. Konstandinides, Division of powers in EU Law, "Wolters Kluwer", Hague, 2009; Josephine Steiner, Lorna Woods, EU Law, "Oxford University Press" Publishing House, New-York, 2009;

P. Craig, Grainne de Burca, EC Law: Texts, Cases \& Materials, "Oxford University Press" Publishing House, Great Britain, 2008;

P.J.G. Kapteyn e.a., The law of the European Union and the European Communities, "Wolters Kluwer" Publishing House, USA-The Netherlands, 2008;

S. Sieberson, Dividing lines between the European Union and its Member States, "T.M.C. Asser Press" Publishing House, Hague, 2008;

http://curia.europa.eu/. 